\title{
Selection of teak clones resistant to the fungus Ceratocystis fimbriata
}

\author{
Seleção de clones de teca resistentes ao fungo Ceratocystis fimbriata
}

\author{
Carlos Alberto da Cunha Oliveira ${ }^{1}$ (D), Geisson Mateus de Jesus Martins ${ }^{1}$ (D), Fernando André Silva Santos ${ }^{1}$ (D), \\ Isabela Vera dos Anjos ${ }^{1}$ (D), Ana Flavia Silva Amorim ${ }^{1}$ (1) , Sandra da Costa Preisigke ${ }^{1}$ (D),

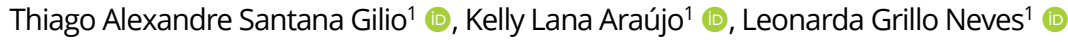 \\ ${ }^{1}$ Universidade do Estado de Mato Grosso - UNEMAT, Cáceres, MT, Brasil
}

How to cite: Oliveira, C. A. C., Martins, G. M. J., Santos, F. A. S., Anjos, I. V., Amorim, A. F. S., Preisigke, S. C., Gilio, T. A. S., Araújo, K. L., \& Neves, L. G. (2021). Selection of teak clones resistant to the fungus Ceratocystis fimbriata. Scientia Forestalis, 49(130), e3553. https://doi.org/10.18671/scifor.v49n130.21

\begin{abstract}
Teak (Tectona grandis L.f) is one of the most used forest species in commercial reforestation in the world and its cultivation has been increasing mainly throughout the regions of tropical and equatorial climate. Currently, one of the main limiting factors for the crop is Ceratocystis wilt, caused by the fungus Ceratocystis fimbriata. Infected teak plants show wood lesions, wilting, and dry pointers. Thus, this study evaluates the reaction of teak genotypes inoculated with $C$. fimbriata. We conducted the experiment in a greenhouse in a randomized block design with 37 treatments (genotypes) and three replicates. We inoculated the fungus 40 days after transplanting the seedlings to the pots. For that, we placed a $3 \mathrm{~mm} \varnothing$ disc of MEA culture medium containing mycelium and reproductive structures of $C$. fimbriata on the stem of teak genotypes, at an approximate height of $3 \mathrm{~cm}$ from the substrate. We submitted the data on lesion area (LA), severity (SEV), lesion length/stem length ratio (LLSL), area under the growth curve of plant height (AUGCPH), and area under the growth curve of collar diameter (AUGCCD) to analysis of variance, and compared the means by the Scott-Knott test at 5\% probability. None of the teak genotypes under study was immune to the fungus C. fimbriata. Genotypes UNEMAT17, UNEMAT16, UNEMAT05, UNEMAT25, and UNEMAT29 performed better for all variables. These results are important for genetic breeding programs on teak resistance to the fungus $C$. fimbriata.
\end{abstract}

Keywords: Tectona grandis; Genetic breeding; Ceratocystis wilt.

\section{Resumo}

A teca (Tectona grandis L.f) é uma das espécies florestais mais utilizadas em reflorestamento comercial no mundo e seu cultivo vem aumentando principalmente ao longo das regiões de clima tropical e equatorial. Atualmente, um dos principais fatores limitantes para a cultura é a murcha-de-ceratocystis, causada pelo fungo Ceratocystis fimbriata. Plantas de teca infectadas apresentam lesões no lenho, murcha e seca dos ponteiros. Assim, o objetivo desse trabalho foi avaliar a reação de genótipos de teca inoculados com C. fimbriata. O experimento foi realizado em casa de vegetação num delineamento experimental de blocos ao acaso, com 37 tratamentos (genótipos) e três repetições. A inoculação do fungo ocorreu aos 40 dias após o transplantio das mudas para os vasos, colocando-se um disco de $3 \mathrm{~mm}$ de $\varnothing$ de meio de cultura MEA contendo micélio e estruturas reprodutivas de $C$. fimbriata no caule dos genótipos de teca, a uma altura aproximada de $3 \mathrm{~cm}$ do substrato. Os dados da área da lesão (AL), severidade (SEV), proporção do comprimento da lesão em relação ao comprimento do caule (PLC), área abaixo da curva de crescimento da altura da planta (AACCAP) e da área abaixo da curva de aumento do diâmetro do colo das plantas (AACADC) foram submetidas a análise de variância e as médias comparadas pelo teste Scott-Knott a $5 \%$ de probabilidade. Nenhum dos genótipos de teca estudados foi imune ao fungo $C$. fimbriata. Os genótipos UNEMAT17, UNEMAT16, UNEMAT05, UNEMAT25 e UNEMAT29 apresentaram melhor desempenho para

Financial support: Nothing to declare.

Conflict of interest: Nothing to declare.

Correspondig author: leonardaneves@unemat.br

Received: 25 May 2020.

Accepted: 30 October 2020.

Editor: Paulo Henrique Müller Silva.

(c) (i) This is an Open Access article distributed under the terms of the Creative Commons Attribution License, which permits unrestricted use, This is an Open Access article distributed under the terms of the Creative Commons Attributi
distribution, and reproduction in any medium, provided the original work is properly cited. 
todas variáveis analisadas. Esses resultados são importantes para o programa de melhoramento genético de teca visando a resistência ao fungo $C$. fimbriata.

Palavras-chave: Tectona grandis; Melhoramento genético; Murcha-de-ceratocystis.

\section{INTRODUCTION}

Teak (Tectona grandis Linn. F.) currently occupies a prominent position in the forestry sector, being one of the most used species of high value for commercial reforestation in the world. There are commercial teak stands in Asia, Africa, South America, Central America and Oceania (Kollert \& Walotek 2015). In Brazil, approximately 93,957 hectares are planted with this species (Indústria Brasileira de Árvores, 2018).

The combination of beauty, resistance, durability and rusticity allows multiple applications of teak wood, mainly: the production of fine furniture, civil and naval construction, being suitable for all types of constructions in and out of water, as it resists the sun, cold, rain and sea water (Kollert \& Cherubini, 2012; Moya et al., 2014; Keogh, 2009).

Several factors can influence the production, quality and durability of teak wood, especially the occurrence of diseases. Currently, one of the main problems of this crop is Ceratocystis wilt, caused by the fungus Ceratocystis fimbriata. Ceratocystis wilt is a lethal disease that has been causing significant losses in teak plantations in Brazil since 2009 (Firmino et al., 2012). External symptoms of Ceratocystis wilt in teak initially consist of wilting of the canopy, branches, or buds, followed by dry pointers and plant death. Internal symptoms consist of wood darkening both radially and longitudinally. The lesions can extend for long distances from roots to wood (Alfenas et al., 2015).

As there are no registered fungicides for teak, the most efficient method of controlling C. fimbriata in areas with a history of Ceratocystis wilt is by breeding, and the planting of resistant genotypes. However, to date, there is no literature reporting of teak resistant genotypes. In view of the above, the present study evaluates the response of teak genotypes to the fungus $C$. fimbriata.

\section{MATERIALS AND METHODS}

We conducted the study at the Mato Grosso State University (UNEMAT), Cáceres Campus, between January and September 2019. The study area is $210 \mathrm{~km}$ away from the state capital, Cuiabá. According to Alvares et al. (2014), the climate of the region is tropical, classified as (Aw), with dry winter, rainy summer, average annual temperature of $26.3^{\circ} \mathrm{C}$, and average annual rainfall of $1335 \mathrm{~mm}$.

\section{Obtaining the isolate}

We obtained the isolate of the fungus $C$. fimbriata from a commercial teak plantation in Cáceres city, Mato Grosso State, Brazil (Figure 1).

We collected samples of teak plants showing typical symptoms of wilt, pointer dryness, and vessel discoloration caused by $C$. fimbriata. Then, we sent the samples to the Genetic Breeding Laboratory of UNEMAT (LMGV), Cáceres Campus, for fungal isolation. We collected these samples from the stem sapwood, at a height of one meter above the ground (Figure 2). 


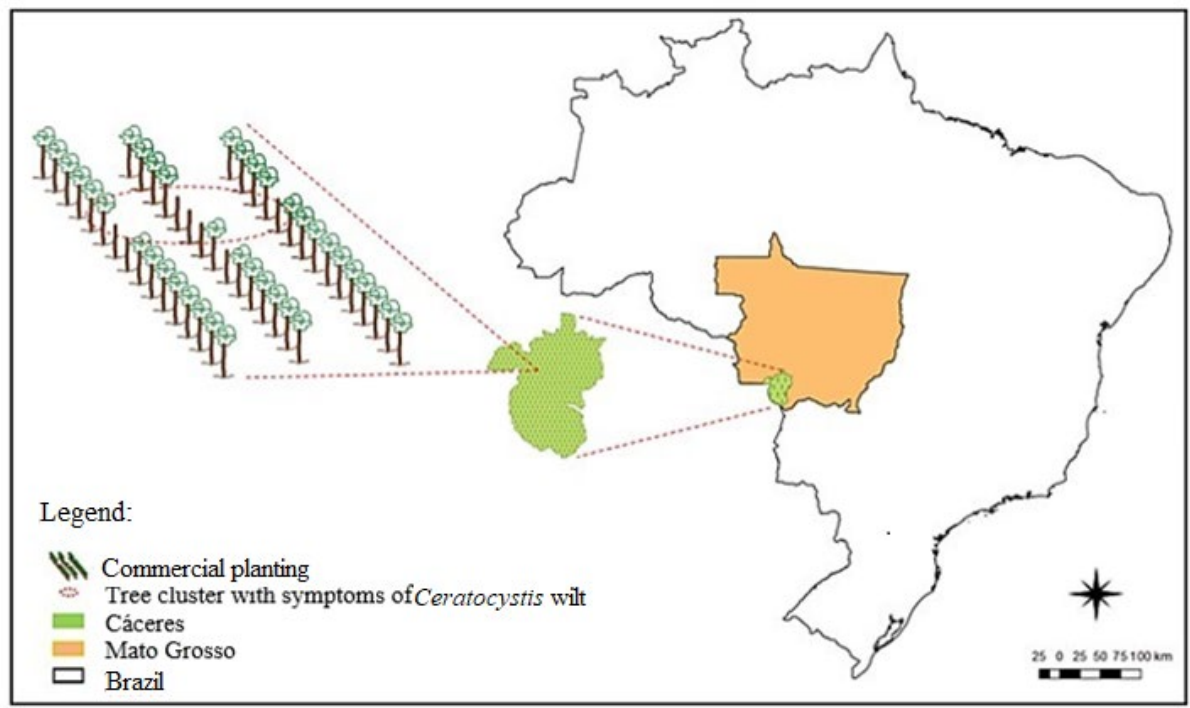

Figure 1: Identification of the collection site of the $C$. fimbriata isolate.
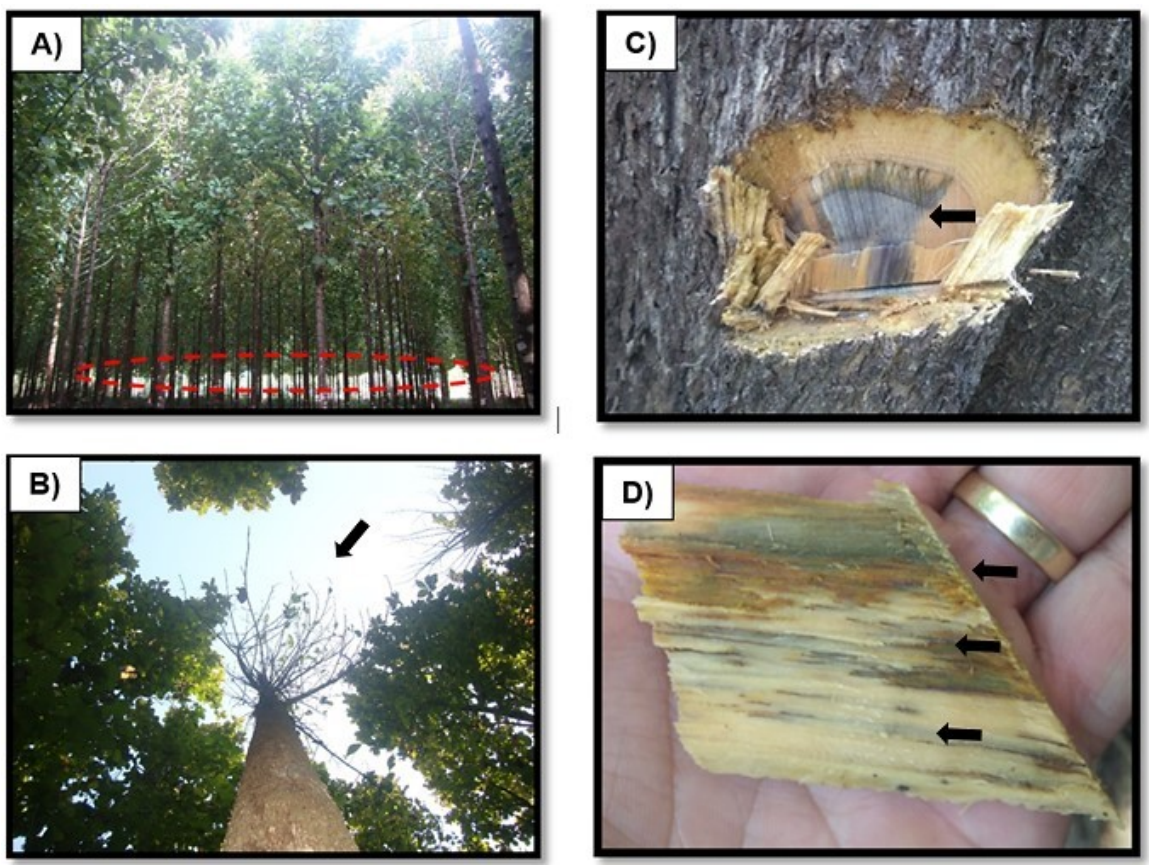

Figure 2. Teak plants with typical symptoms of wilting, pointer drying, and vessel discoloration caused by C. fimbriata. A) Tree cluster with dead trees and bordered by plants with symptoms of wilting and pointer drying; B) Teak plant with symptoms of pointer drying (arrow); C) Sapwood region of a teak plant, where the authors collected samples for fungal isolation. Arrow indicates vessel discoloration; D) Detail of sapwood with symptoms of vessel discoloration (arrows).

\section{Isolating and obtaining the pure culture}

We isolated the fungus using the carrot bait method (Moller and Devay, 1968). After colonization and reproduction of pathogens on the bait, we removed a mass of ascospores from the apex of perithecia. Then, we transferred this mass to Petri dishes containing malt extract agar (MEA) culture medium. Subsequently, we incubated these dishes in Bio-Oxygen Demand Incubator at $25 \pm 2{ }^{\circ} \mathrm{C}$, with a 12-hour photoperiod, for purifying and obtaining a pure culture of the isolate (Figure 3). After obtaining the pure culture, we stored the isolate at $5{ }^{\circ} \mathrm{C}$ using the Castellani method (Castellani, 1939), and deposited it in the fungal collection of LMGV. 

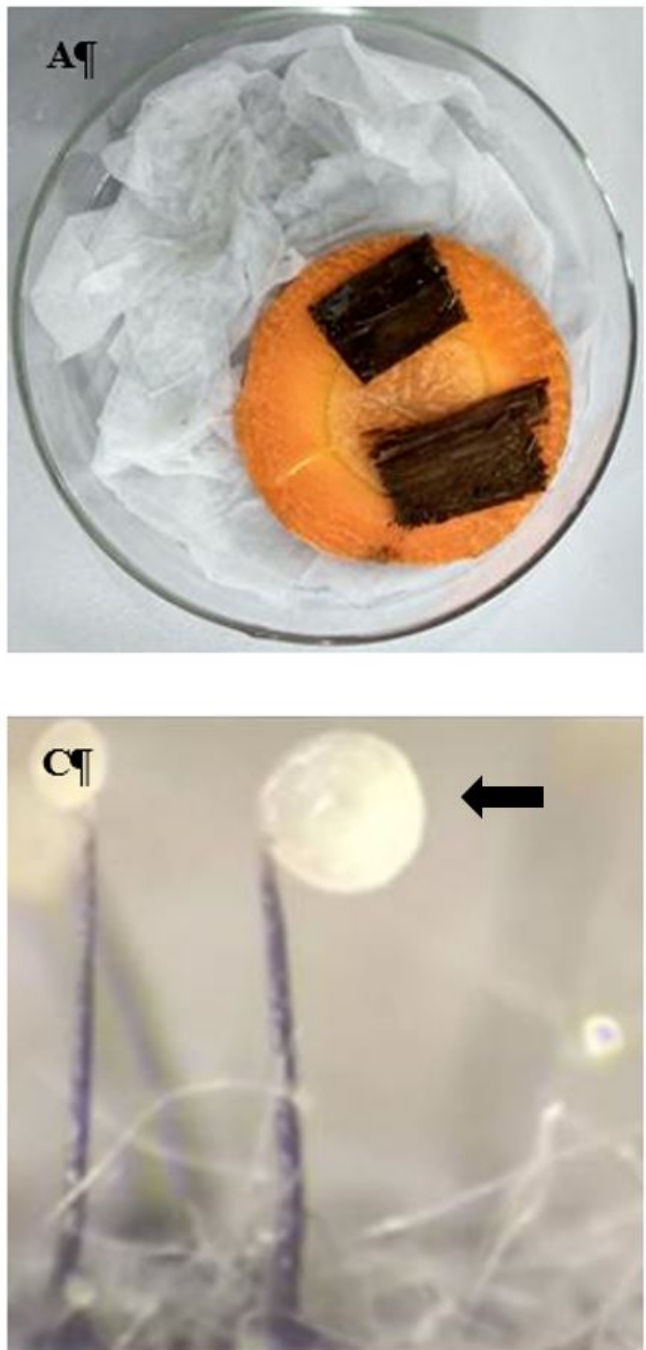
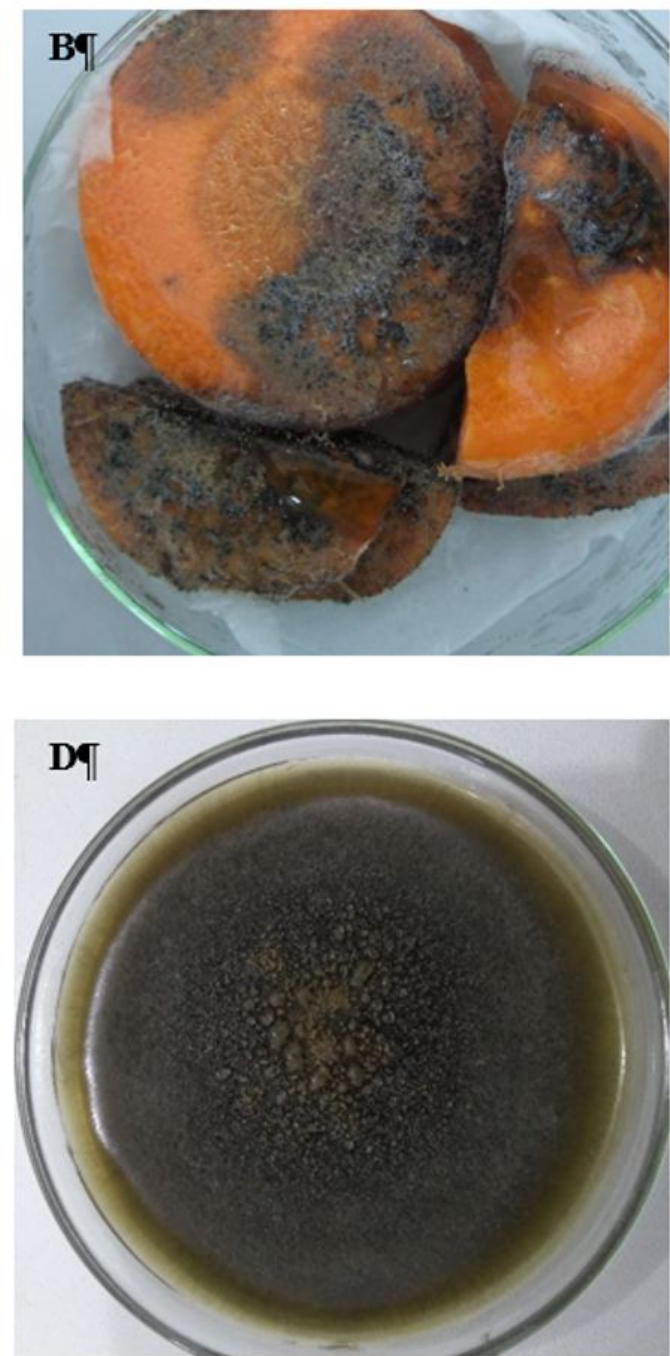

Figure 3. Process of isolation of C. fimbriata using the carrot bait method (Moller And Devay, 1968). A) Deposition of fragments of approximately $1 \mathrm{~cm}^{2}$ of each collected sample on carrot discs;

B) Colonization and production of C. fimbriata perithecia in carrot baits; C) Detail of ascospore mass (arrow) at the apex of perithecium; D) Pure culture of a C. fimbriata isolate in MEA culture medium.

\section{Plant material}

We evaluated 37 teak genotypes belonging to the LMGV teak germplasm bank, producing clonal seedlings of these genotypes in tubes. When these seedlings were approximately $15 \mathrm{~cm}$ high, we transplanted them into 3-liter pots containing 1.8 liters (L) of washed sand and 1 liter (L) of a substrate with the following formulation: pine bark, ash, vermiculite, sawdust, bio-stabilizers, additives, $0.50 \%$ acidity correctives, $0.50 \%$ natural phosphate, and NPK.

After transplanting the seedlings, we stored them in pots in a greenhouse with temperature ranging from 30 to $42{ }^{\circ} \mathrm{C}$ and relative humidity of 60 to $70 \%$. We used microsprinkler irrigation in the first month of the experiment. From the second month on, we used drip irrigation so as to minimize nutrient loss, avoiding the umbrella effect and, mainly, the appearance of leaf diseases. Supplementary solid fertilization started eight days after planting. For that, we used potassium chloride (KCL), triple superphosphate (TSP), micronutrients (FTE), plaster $\left(\mathrm{CaSO}_{4} \cdot 2 \mathrm{H}_{2} \mathrm{O}\right)$, and ammonium nitrate $\left(\mathrm{NH}_{4} \mathrm{NO}_{3}\right)$. We applied this fertilization at two separate points (Figure 4). Supplementary foliar fertilization took place 20 days after planting. For that, we used a water-soluble organic-mineral fertilizer with a balanced formulation of micro- and macronutrients and free amino acids (Table 1 ). 


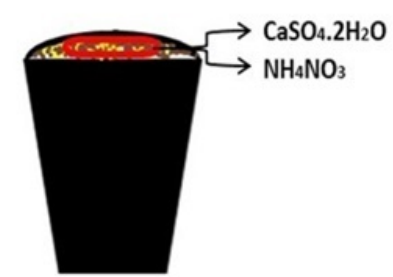

two days before planting

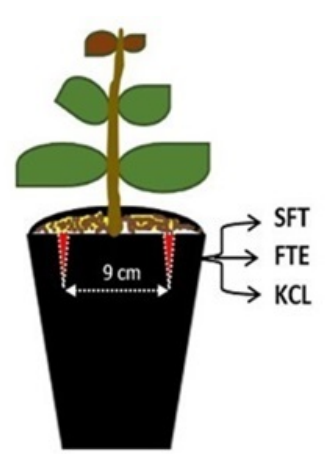

one day after planting

Figure 4. Cover fertilization in the pots.

Table 1 - Fertilizer concentration for foliar maintenance

\begin{tabular}{|c|c|}
\hline ITEM & DESCRIPTION \\
\hline Nitrogen & $5.0 \% \mathrm{p} / \mathrm{p} ;(70.0 \mathrm{~g} / \mathrm{L})$ \\
\hline Phosphorus $\left(\mathrm{P}_{2} \mathrm{O}_{5}\right)$ & $6.0 \% \mathrm{p} / \mathrm{p} ;(84.0 \mathrm{~g} / \mathrm{L})$ \\
\hline Potassium $\left(\mathrm{K}_{2} \mathrm{O}\right)$ & $6.0 \% \mathrm{p} / \mathrm{p} ;(84.0 \mathrm{~g} / \mathrm{L})$ \\
\hline Calcium & 1.0\% p/p; (14.0g/L) \\
\hline Magnesium & $0.5 \% \mathrm{p} / \mathrm{p} ;(7.0 \mathrm{~g} / \mathrm{L})$ \\
\hline Boron & $0.5 \% \mathrm{p} / \mathrm{p} ;(7.0 \mathrm{~g} / \mathrm{L})$ \\
\hline Copper & $0.2 \% \mathrm{p} / \mathrm{p} ;(2.8 \mathrm{~g} / \mathrm{L})$ \\
\hline Iron & $0.1 \% \mathrm{p} / \mathrm{p} ;(1.4 \mathrm{~g} / \mathrm{L})$ \\
\hline Manganese & $0.5 \% \mathrm{p} / \mathrm{p} ;(7.0 \mathrm{~g} / \mathrm{L})$ \\
\hline Molybdenum & $0.1 \% \mathrm{p} / \mathrm{p} ;(1.4 \mathrm{~g} / \mathrm{L})$ \\
\hline Zinc & $1.0 \% \mathrm{p} / \mathrm{p} ;(14.0 \mathrm{~g} / \mathrm{L})$ \\
\hline Total Organic Carbon: & $6.0 \% \mathrm{p} / \mathrm{p} ;(84.0 \mathrm{~g} / \mathrm{L})$ \\
\hline Density at $20^{\circ} \mathrm{C}$ : & $1.40 \mathrm{~g} / \mathrm{cm}^{3}$ \\
\hline Physical Nature (fluid): & Homogeneous suspension \\
\hline
\end{tabular}

\section{Inoculation of genotypes}

For seedling inoculation, we transferred fragments of culture medium with C. fimbriata, stored by the Castellani method, to glass Petri dishes containing MEA culture medium. Subsequently, we incubated these dishes in B.O.D. chambers at $25 \pm 2{ }^{\circ} \mathrm{C}$, with a photoperiod of 12 hours, for fifteen days.

We inoculated the fungus 40 days after transplanting the seedlings to the pots, following the methodology proposed by Al-Sadi et al. (2010) with modifications. For that, we used a stopper puncher to make a small opening of $3.5 \mathrm{~mm}$ in diameter $(\varnothing)$ in the stem of teak genotypes at a height of approximately $3 \mathrm{~cm}$ from the substrate, subsequently removing the bark and phloem. Then, we introduced a $3 \mathrm{~mm} \varnothing$ disc of MEA culture medium containing mycelium and reproductive structures of $C$. fimbriata. We wrapped the inoculated region for 120 hours with cotton wool moistened with distilled and autoclaved water and protected it with PVC film (Figure 5C). We kept the inoculated plants in the greenhouse for 126 days. In control plants of all genotypes, the process was the same as previously described, however, without deposition of the inoculum. 

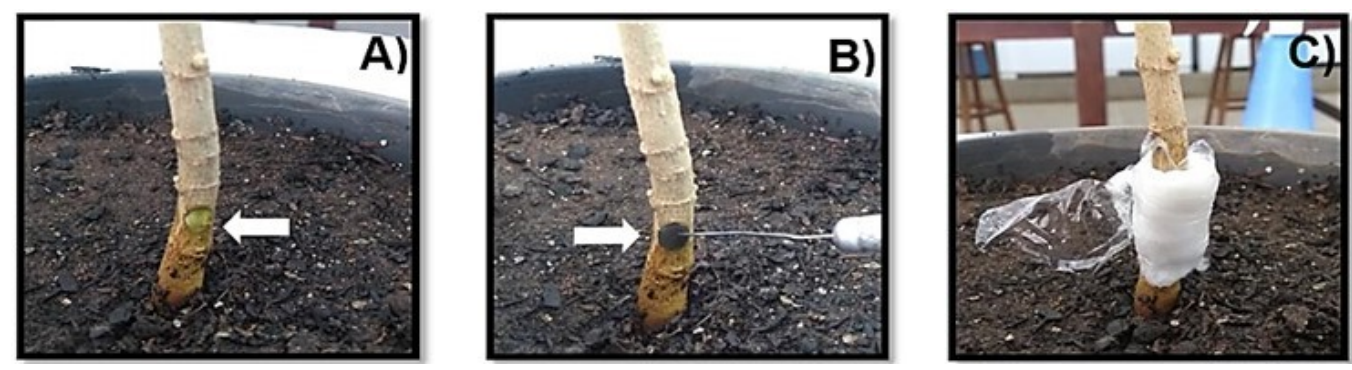

Figure 5. Inoculation of teak genotypes. A) Orifice (arrow) of $3.5 \mathrm{~mm} \varnothing$ made at a height of $3 \mathrm{~cm}$ from the substrate for subsequent removal of the bark and phloem from the stem; B) Introduction of a $3 \mathrm{~mm} \varnothing$ disk of MEA culture medium containing mycelium and reproductive structures of $C$. fimbriata in the orifice; C) PVC film and moistened cotton wool wrapping the inoculated region.

\section{Characteristics evaluated}

\section{Genotype growth characteristics}

To quantify the growth of teak genotypes inoculated with $C$. fimbriata, we made ten estimates of plant height (PH) and collar diameter (CD). These estimates took place at intervals of approximately twelve days. To measure plant height $(\mathrm{PH})$, we positioned a millimeter ruler at the substrate level up to the apical meristem of the seedling. To measure collar diameter (CD), we used a digital caliper. We used these variables to calculate the area under the growth curve of plant height (AUGCPH) and the area under the growth curve of collar diameter (AUGCCD), following the equation proposed by Shaner \& Finney (1977).

\section{Resistance characteristics}

To quantify the resistance responses of the different teak genotypes to the $C$. fimbriata isolate, we cut and photographed the plants vertically 126 days after inoculation. Subsequently, we used the ImageJ software ((https://imagej.net/Citing) to measure lesion area $(\mathrm{LA})$, stem area (SA), lesion length (LL), and stem length (SL). We calculated the severity of the disease (SEV) in xylem vessels by the ratio between SA and LA. Moreover, we used LL and SL to calculate the lesion length/stem length ratio (LLSL), according to the formula proposed by Gomes et al. (2019):

$\mathrm{LLSL}=(\mathrm{LL} * \times 100) / \mathrm{SL}$

To complete Koch's postulate, we collected segments of the symptomatic tissue from each genotype for re-isolation using the carrot bait method (Moller And Devay 1968).

\section{Experimental design and statistical analysis}

We conducted the experiment in a randomized block design with 37 treatments (teak genotypes) and three replicates. Each experimental plot consisted of three plants. We submitted the variables AUGCPH, AUGCCD, SEV, LA, and LLSL to analysis of variance, and grouped the means using the Scott-Knott test at 5\% probability. We performed all statistical analyses using the Genes program (Cruz, 2006).

\section{RESULTS AND DISCUSSION}

Throughout the experiment, none of the inoculated plants showed symptoms of wilting or pointer drying. Studies report the occurrence of these symptoms in susceptible plants about twenty days after inoculation (DAI) in eucalyptus (Silva et al., 2018), and thirteen DAl in mango (Araujo et al., 2014). However, other studies also observed a lack of 
wilting and pointer drying symptoms in plants inoculated with C. fimbriata (Zauza et al., 2004; Gomes et al., 2019).

These differences may be due to the inoculation method (Mafia et al., 2011), experimental period (Gomes et al., 2019; Mafia et al., 2011), age of the inoculated plant (Firmino et al., 2013), and differences in aggressiveness between the inoculated isolates (Harrington et al., 2011; Firmino et al., 2013; Valdetaro et al., 2015). Another factor which may have influenced this study was that the temperature in the greenhouse ranged from 30 to $42{ }^{\circ} \mathrm{C}$, with a relative humidity of 60 to $70 \%$. As these conditions are ideal for teak development (Pandey \& Brown, 2000), the speed of increase in the diameter and height of the genotypes was probably greater than the rate of pathogen growth in xylem vessels longitudinally and, mainly, radially.

Experimental temperatures may also have influenced the development of the disease (Silva et al., 2017). Thus, there was not enough time for total blockage in the transport of water and nutrients and, consequently, for external manifestation of wilting and pointer drying. Wilt occurs as a result of the collapse and total obstruction of xylem vessels due to the presence of pathogen structures such as hyphae and spores (Parke et al., 2007); the degradation of the wall of these vessels by the pathogen (Araujo et al., 2014); and the reaction of the plant to the presence of the pathogen, forming, for example, tyloses (Firmino et al., 2018).

Control plants did not show typical symptoms of the disease. All inoculated plants had lesions consisting of discoloration and necrosis of xylem vessels. This shows that none of the genotypes was immune to the pathogen; however, they had different resistance responses. Some studies reported variation in resistance between genotypes in other hosts, such as Eucalyptus spp. (Zauza et al., 2004; Firmino et al., 2013) and Mangifera indica L (Araujo et al., 2014; Oliveira et al., 2016). For these species, the use of resistant plants is an important measure of management of the pathogen in areas with a history of occurrence of Ceratocystis wilt (Alfenas et al., 2015).

The analysis of variance (Table 2) for lesion area (LA), severity (SEV), lesion length/stem length ratio (LLSL), area under the growth curve of plant height (AUGCPH), and area under the growth curve of collar diameter (AUGCCD) showed significant differences by the $\mathrm{F}$ test at $1 \%$ probability for all variables, except for LLSL. This variable has been used in some studies to evaluate the different reaction between genotypes regarding infection by C. fimbriata (Gomes et al., 2019; Oliveira et al., 2016).

However, the present study showed different patterns of lesions, with pathogen growth both longitudinally and radially. These lesions occurred far from the inoculation point, which may, in some cases, lead to an underestimation of the intensity of the disease. Consequently, the variable LLSL may vary largely (Oliveira, 2017). The results corroborate this assertion since this variable showed the highest coefficient of variation (Table 2). These facts show the need to use other variables to analyze genetic resistance to the fungus C. fimbriata, as already proposed by Mafia et al. (2011).

Table 2 - Analysis of variance for the variables lesion area (LA), severity (SEV), lesion length/stem length ratio (LLSL), area under the growth curve of plant height (AUGCPH), and area under the growth curve of collar diameter (AUGCCD) in teak genotypes inoculated with C. fimbriata. Cáceres, 2019.

\begin{tabular}{|c|c|c|c|c|c|c|}
\hline \multicolumn{7}{|c|}{ Mean Squares } \\
\hline SV & DF & LA & SEV & LLSL & AUGCPH & AUGCCD \\
\hline Block & 2 & 13.85 & 71.48 & 184.84 & $1,621,635.83$ & $34,962.83$ \\
\hline Treatment & 36 & $6.72 * \star$ & $15.31 * *$ & $56.04^{\mathrm{ns}}$ & $2,563,363.20 * *$ & $42,988.29 * *$ \\
\hline Residue & 72 & 1.42 & 5.43 & 35.85 & $780,521.55$ & $18,397.58$ \\
\hline Mean & & 2.78 & 5.68 & 12.51 & $4,612.74$ & $1,660.41$ \\
\hline CV\% & & 42.89 & 40.99 & 47.85 & 19.15 & 8.17 \\
\hline
\end{tabular}

** and * significant at 1 and $5 \%$ probability, respectively, by the $\mathrm{F}$ test. ${ }^{\mathrm{ns}}$ nonsignificant by the $\mathrm{F}$ test. 
The authors of the present study divided the teak genotypes into four groups depending on lesion area (LA) (Table 3). Of the 37 genotypes under study, 28 belonged to the group with the highest resistance to the fungus $C$. fimbriata, with an average LA ranging from $0.87 \mathrm{~cm}^{2}$ to $3.81 \mathrm{~cm}^{2}$. These genotypes showed a reduction in the longitudinal colonization of the pathogen, with concentration of necrosis close to the inoculation site (Figure 6A). Most of these genotypes had no lesion in the collar region (Figure 7A). The intermediate group comprised the following genotypes: UNEMAT26, UNEMAT13, UNEMAT23, UNEMAT03, UNEMAT19, UNEMAT28, and UNEMAT09. In these genotypes, LA ranged from $3.52 \mathrm{~cm}^{2}$ to $4.58 \mathrm{~cm}^{2}$, with necrosis also concentrating close to the inoculation site (Figure 6B) and, in some cases, reaching the plant collar (Figure 7B). Genotype UNEMATO2 was the most susceptible, with an average LA of $8.54 \mathrm{~cm}^{2}$, followed by UNEMATO7, with an average LA of $6.38 \mathrm{~cm}^{2}$. These genotypes showed wood darkening both radially and longitudinally, with lesions extending for long distances from the inoculation point (Figures 6C and 6D) and reaching the plant collar (Figures 7C and 7D). Some genotypes showed discontinuous symptoms in the longitudinal direction (Figure 6D). Ferreira et al. (2006) also observed this discontinuity when studying symptoms of $C$. fimbriata wilt in Eucalyptus.

For the other variables, the authors of the present study divided the genotypes into only two groups (Table 3). Genotypes UNEMAT08, UNEMAT01, UNEMAT35, UNEMAT11, UNEMAT34, UNEMAT21, and UNEMAT33 made up the group with the highest SEV. However, they were also in the group with the lowest LA. Due to their genetic characteristics, these clones developed less, presenting a higher percentage of internal tissues with symptoms of the disease. Among the most resistant genotypes, only UNEMAT17, UNEMAT16, UNEMAT05, UNEMAT25, and UNEMAT29 had higher AUGCPH and AUGCCD. Genotype UNEMAT02, even with the highest LA among all genotypes under study, was in the group that had the highest AUGCPH. However, the greater the intensity of Ceratocystis wilt, the greater the damage to wood quality and durability (Mafia et al., 2013).

Table 3. Lesion area (LA), severity (SEV), area under the growth curve of plant height (AUGCPH), and area under the growth curve of collar diameter (AUGCCD) in teak genotypes inoculated with $C$. fimbriata. Cáceres, 2019.

\begin{tabular}{ccccc}
\hline GenOtype & LA $\left(\mathbf{c m}^{2}\right)$ & SEV $(\%)$ & AUGCPH & AUGCCD \\
\hline UNEMAT02 & $8.54 \mathrm{a}$ & $9.55 \mathrm{a}$ & $5,501.41 \mathrm{a}$ & $1,506.71 \mathrm{~b}$ \\
UNEMAT07 & $6.38 \mathrm{~b}$ & $12.64 \mathrm{a}$ & $4,555.75 \mathrm{~b}$ & $1,640.29 \mathrm{~b}$ \\
UNEMAT26 & $4.58 \mathrm{c}$ & $7.09 \mathrm{a}$ & $6,256.13 \mathrm{a}$ & $1,447.51 \mathrm{~b}$ \\
UNEMAT13 & $4.48 \mathrm{c}$ & $7.70 \mathrm{a}$ & $4,531.49 \mathrm{~b}$ & $1,779.29 \mathrm{a}$ \\
UNEMAT23 & $3.98 \mathrm{c}$ & $8.19 \mathrm{a}$ & $4,187.57 \mathrm{~b}$ & $1,846.58 \mathrm{a}$ \\
UNEMAT03 & $3.81 \mathrm{c}$ & $9.74 \mathrm{a}$ & $3,574.67 \mathrm{~b}$ & $1,695.99 \mathrm{a}$ \\
UNEMAT19 & $3.80 \mathrm{c}$ & $6.74 \mathrm{a}$ & $6,386.57 \mathrm{a}$ & $1,669.88 \mathrm{a}$ \\
UNEMAT28 & $3.78 \mathrm{c}$ & $5.06 \mathrm{~b}$ & $6,041.22 \mathrm{a}$ & $1,765.12 \mathrm{a}$ \\
UNEMAT09 & $3.52 \mathrm{c}$ & $8.89 \mathrm{a}$ & $3,735.65 \mathrm{~b}$ & $1,676.23 \mathrm{a}$ \\
UNEMAT17 & $3.31 \mathrm{~d}$ & $5.24 \mathrm{~b}$ & $6,084.13 \mathrm{a}$ & $1,828.11 \mathrm{a}$ \\
UNEMAT08 & $3.20 \mathrm{~d}$ & $6.57 \mathrm{a}$ & $4,319.44 \mathrm{~b}$ & $1,623.35 \mathrm{~b}$ \\
UNEMAT01 & $2.92 \mathrm{~d}$ & $6.28 \mathrm{a}$ & $4,109.72 \mathrm{~b}$ & $1,584.80 \mathrm{~b}$ \\
UNEMAT35 & $2.89 \mathrm{~d}$ & $6.44 \mathrm{a}$ & $3,337.23 \mathrm{~b}$ & $1,832.17 \mathrm{a}$ \\
UNEMAT11 & $2.86 \mathrm{~d}$ & $6.32 \mathrm{a}$ & $4,100.38 \mathrm{~b}$ & $1,589.79 \mathrm{~b}$ \\
UNEMAT31 & $2.71 \mathrm{~d}$ & $5.62 \mathrm{~b}$ & $5,415.12 \mathrm{a}$ & $1,522.19 \mathrm{~b}$ \\
\hline
\end{tabular}

Means followed by the same letter do not differ by the Scott-Knott test at 5\% probability. 
Table 3. Continued...

\begin{tabular}{ccccc}
\hline GenOtype & LA $\left(\mathbf{c m}^{2}\right)$ & SEV $(\%)$ & AUGCPH & AUGCCD \\
\hline UNEMAT16 & $2.67 \mathrm{~d}$ & $4.32 \mathrm{~b}$ & $5,436.62 \mathrm{a}$ & $1,788.53 \mathrm{a}$ \\
UNEMAT05 & $2.65 \mathrm{~d}$ & $5.20 \mathrm{~b}$ & $5,059.86 \mathrm{a}$ & $1,710.24 \mathrm{a}$ \\
UNEMAT06 & $2.63 \mathrm{~d}$ & $4.47 \mathrm{~b}$ & $5,411.77 \mathrm{~b}$ & $1,681.38 \mathrm{a}$ \\
UNEMAT34 & $2.48 \mathrm{~d}$ & $7.87 \mathrm{a}$ & $3,293.98 \mathrm{~b}$ & $1,665.04 \mathrm{a}$ \\
UNEMAT24 & $2.38 \mathrm{~d}$ & $4.99 \mathrm{~b}$ & $4,589.83 \mathrm{~b}$ & $1,738.58 \mathrm{a}$ \\
UNEMAT04 & $2.35 \mathrm{~d}$ & $5.78 \mathrm{~b}$ & $4,104.11 \mathrm{~b}$ & $1,630.53 \mathrm{~b}$ \\
UNEMAT25 & $2.26 \mathrm{~d}$ & $3.51 \mathrm{~b}$ & $5,857.9 \mathrm{a}$ & $1,812.63 \mathrm{a}$ \\
UNEMAT30 & $2.26 \mathrm{~d}$ & $5.09 \mathrm{~b}$ & $4,280.66 \mathrm{~b}$ & $1,649.59 \mathrm{~b}$ \\
UNEMAT21 & $2.23 \mathrm{~d}$ & $6.39 \mathrm{a}$ & $3,638.25 \mathrm{~b}$ & $1,556.14 \mathrm{~b}$ \\
UNEMAT12 & $2.10 \mathrm{~d}$ & $5.76 \mathrm{~b}$ & $4,006.35 \mathrm{~b}$ & $1,641.90 \mathrm{~b}$ \\
UNEMAT33 & $2.04 \mathrm{~d}$ & $6.29 \mathrm{a}$ & $4,104.87 \mathrm{~b}$ & $1,451.48 \mathrm{~b}$ \\
UNEMAT20 & $1.98 \mathrm{~d}$ & $3.92 \mathrm{~b}$ & $4,909.99 \mathrm{a}$ & $1,623.42 \mathrm{~b}$ \\
UNEMAT36 & $1.94 \mathrm{~d}$ & $5.05 \mathrm{~b}$ & $3,721.67 \mathrm{~b}$ & $1,895.15 \mathrm{a}$ \\
UNEMAT18 & $1.89 \mathrm{~d}$ & $4.02 \mathrm{~b}$ & $4,739.44 \mathrm{~b}$ & $1,679.16 \mathrm{a}$ \\
UNEMAT10 & $1.80 \mathrm{~d}$ & $4.04 \mathrm{~b}$ & $4,952.29 \mathrm{a}$ & $1,455.53 \mathrm{~b}$ \\
UNEMAT29 & $1.60 \mathrm{~d}$ & $2.30 \mathrm{~b}$ & $5,497.69 \mathrm{a}$ & $1,731.32 \mathrm{a}$ \\
UNEMAT37 & $1.43 \mathrm{~d}$ & $4.29 \mathrm{~b}$ & $3,943.90 \mathrm{~b}$ & $1,751.10 \mathrm{a}$ \\
UNEMAT27 & $1.42 \mathrm{~d}$ & $3.30 \mathrm{~b}$ & $3,940.59 \mathrm{~b}$ & $1,627.78 \mathrm{~b}$ \\
UNEMAT15 & $1.23 \mathrm{~d}$ & $2.44 \mathrm{~b}$ & $4,504.19 \mathrm{~b}$ & $1,757.74 \mathrm{a}$ \\
UNEMAT22 & $1.10 \mathrm{~d}$ & $4.47 \mathrm{~b}$ & $2,974.78 \mathrm{~b}$ & $1,515.48 \mathrm{~b}$ \\
UNEMAT32 & $0.93 \mathrm{~d}$ & $1.79 \mathrm{~b}$ & $5,967.92 \mathrm{a}$ & $1,619.81 \mathrm{~b}$ \\
UNEMAT14 & $2.95 \mathrm{~b}$ & $3,598.19 \mathrm{~b}$ & $1,444.60 \mathrm{~b}$ \\
\hline
\end{tabular}

Means followed by the same letter do not differ by the Scott-Knott test at 5\% probability.

Some researchers reported the mechanisms of resistance to Ceratocystis wilt in other species. Silva et al. (2020) studied the histopathological response of Eucalyptus urophylla $\times$ Eucalyptus grandis clones resistant and susceptible to C. fimbriata. The authors found that the limitation in pathogen colonization in xylem vessels in resistant clones was mainly due to a rapid response to infection. This response consisted of the intense formation of tyloses and gels and the accumulation of phenolic compounds, calcium oxalate, and lignin. Araujo et al. (2014) evidenced similar defense reactions in a resistant mango cultivar. In addition, Firmino et al. (2018) observed lignin accumulation in Eucalyptus plants resistant to Ceratocystis wilt. It is noteworthy that only recently have researchers identified C. fimbriata in teak (Firmino et al., 2012). Thus, there are few studies on this patho-system (Valdetaro, 2016). To date, none of these studies addressed neither structural and biochemical defense mechanisms nor the genes that confer resistance.

The genotypes with the greatest potential for resistance in the present study are promising for the teak breeding program. Notwithstanding, studies on the genetic resistance of this crop to the fungus $C$. fimbriata are still in their initial stages. Researchers have reported genetic and pathogenic variability among $C$. fimbriata isolates from various species (Harrington et al., 2011; Firmino et al., 2013; Valdetaro et al., 2015). This shows the need to evaluate the reaction of these genotypes to other isolates of the fungus. Furthermore, researchers should consider longer evaluation periods for these genotypes, evaluating other methods of pathogen inoculation and the influence of plant age on resistance. 

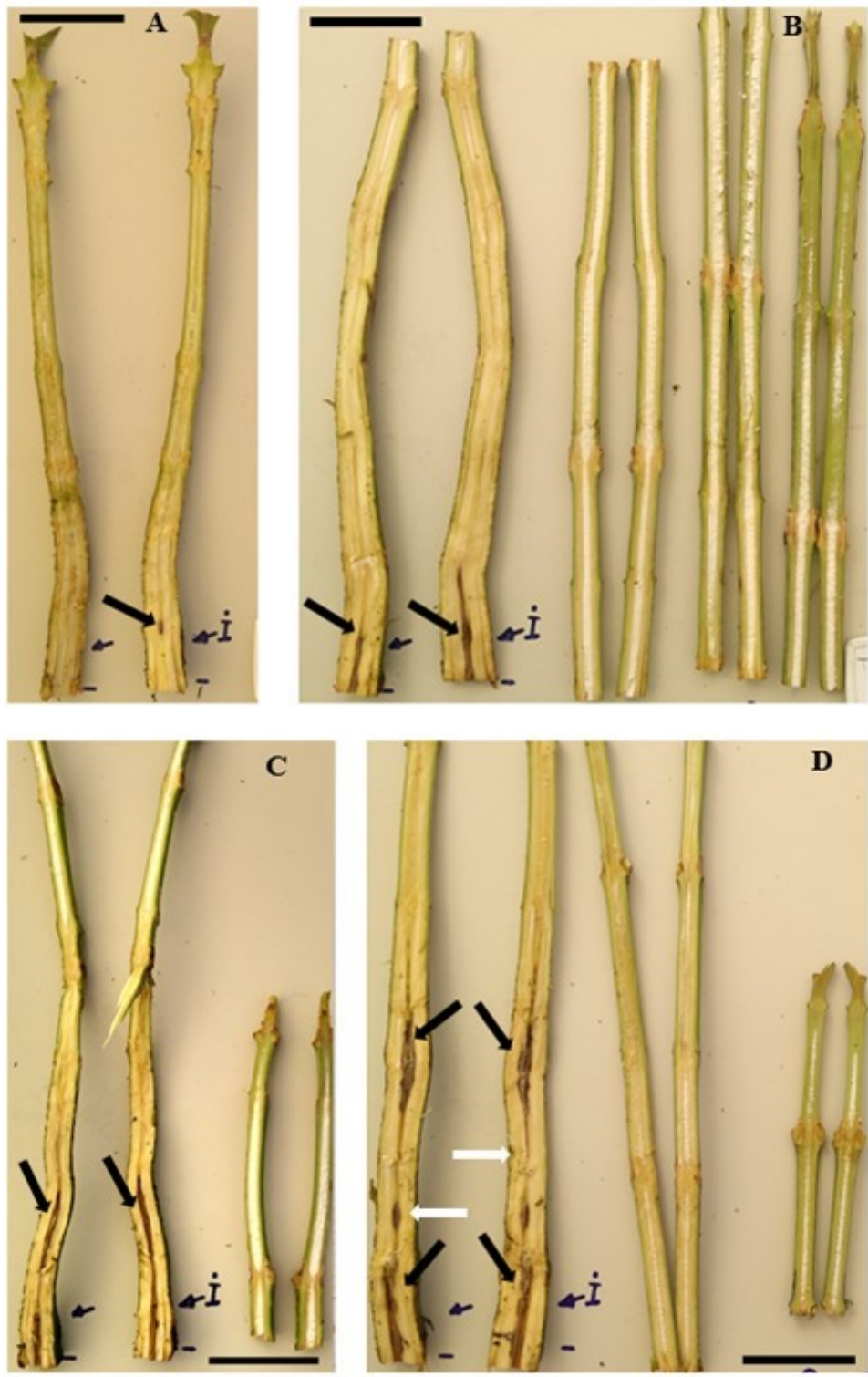

Figure 6. Teak genotypes cut longitudinally, showing colonization of the pathogen in the vascular bundles, 126 days after inoculation with C. fimbriata. A) UNEMAT 32; B) UNEMAT 28; C) UNEMAT 7; D) UNEMAT 2. I - Indicates the inoculation site. Black arrows indicate lesions caused by C. fimbriata; white arrows indicate lesion discontinuity in the longitudinal direction. Scale bar $=5 \mathrm{~cm}$.
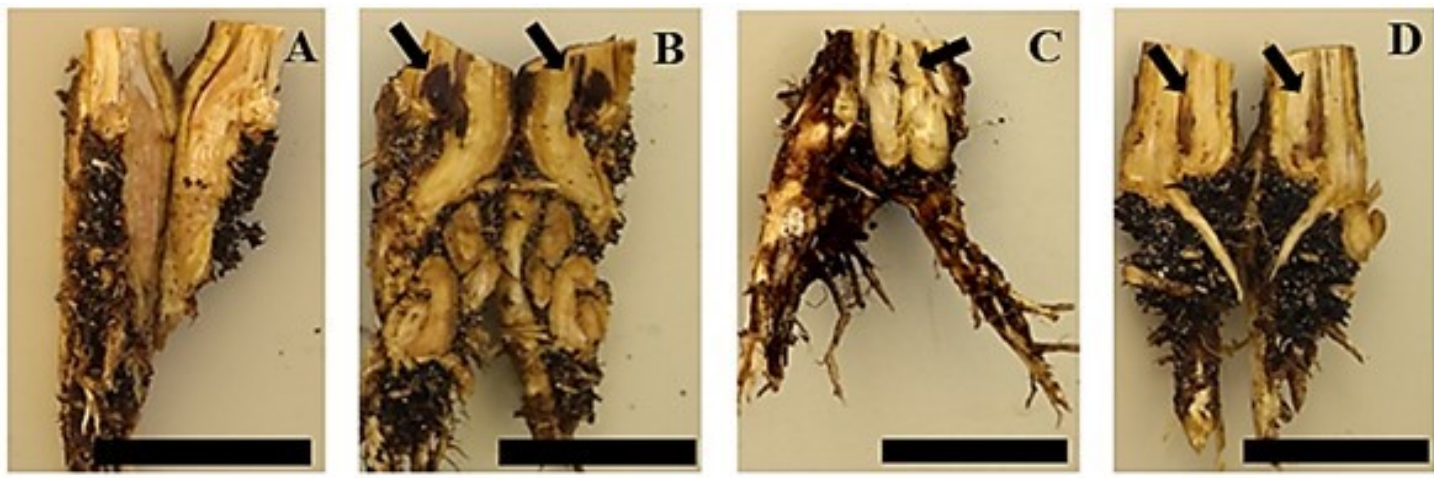

Figure 7. Collar region of teak genotypes cut longitudinally, showing colonization of the pathogen in the vascular bundles, 126 days after inoculation with C. fimbriata. A) UNEMAT 32; B) UNEMAT 28;

C) UNEMAT 7; D) UNEMAT 2. Black arrows indicate lesions caused by $C$. fimbriata. Scale bar $=5 \mathrm{~cm}$. 


\section{CONCLUSIONS}

- None of the teak genotypes under study was immune to the fungus $C$. fimbriata;

- Genotypes UNEMAT17, UNEMAT16, UNEMAT05, UNEMAT25, and UNEMAT29 performed better for all the variables under study.

\section{REFERENCES}

Alfenas, A. C., Guimarães, L. M. S., Oliveira, L. S. S., \& Ferreira, M. A. (2015). Impactos da murcha-deCeratocystis causada por Ceratocystis fimbriata em espécies florestais e frutíferas. In: A. A. Colmán, A. V. Barros, F. J. Machado, M. A. Silva, N. P. Caires \& P. A. Soares (Eds). Doenças em espécies florestais e frutíferas (Vol. 1, pp. 15-35). Viçosa: Editora UFV.

Al-Sadi, A. M., Al-Ouweisi, F. A., Al-Shariani, N. K., Al-Adawi, A. O., Kaplan, E. J., \& Deadman, M. L. (2010). Histological changes in mango seedlings following infection with Ceratocystis manginecans, the cause of mango decline. Journal of Phytopathology, 158(11-12), 738-743. http://dx.doi.org/10.1111/j.1439-0434.2010.01691.x.

Alvares, C. A., Stape, J. L., Sentelhas, P. C., de Moraes Gonçalves, J. L., \& Sparovek, G. (2014). Köppen's climate classification map for Brazil. Meteorologische Zeitschrift (Berlin), 22(6), 711-728. http://dx.doi.org/10.1127/0941-2948/2013/0507.

Araujo, L., Silva Bispo, W. M., Cacique, I. S., Cruz, M. F. A., \& Rodrigues, F. A. (2014). Histopathological aspects of mango resistance to the infection process of Ceratocystis fimbriata. Plant Pathology, 63(6), 1282-1295. http://dx.doi.org/10.1111/ppa.12208.

Castellani, A. (1939). Viability of some pathogenic fungi in distilled water. The Journal of Tropical Medicine and Hygiene, 24, 270-276.

Cruz, C. D. (2006). Programa genes: estatística experimental e matrizes (285 p.). Viçosa: Editora UFV.

Ferreira, F. A., Maffia, L. A., Barreto, R. W., Demuner, N. L., \& Pigatto, S. (2006). Sintomatologia da murcha de Ceratocystis fimbriata em eucalipto. Revista Árvore, 30(2), 155-162. http://dx.doi.org/10.1590/S0100-67622006000200001.

Firmino, A. C., Tozze Junior, H. J., Souza, I. C. G., \& Furtado, E. L. (2013). Resistência de genótipos de Eucalipto a Ceratocystis spp. Scientia Forestalis, 41(98), 165-173.

Firmino, A. C., Tozze Junior, H. J., \& Furtado, E. L. (2012). First report of Ceratocystis fimbriata causing wilt in Tectona grandis in Brazil. New Disease Reports, 25, 24. http://dx.doi.org/10.5197/j.20440588.2012.025.024.

Firmino, A. C., Tozze Junior, H. J., Viana, C. M., Soliman, E. P., Souza, I. C. G., Silva, M. R., Tristão, L. E., \& Furtado, E. L. (2018). Análise histológica de plantas de eucalipto resistentes e suscetíveis inoculadas com Ceratocystis fimbriata. Scientia Forestalis, 46(118), 209-216. http://dx.doi.org/10.18671/scifor.v46n118.07.

Gomes, C. A. F. C., Pereira, F. B., Garcia, F. A., Garret, A. T. A., Siqueira, L., \& Tambarussi, E. V. (2019). Inoculação de Ceratocystis fimbriata Ellis \& Halsted em Eucalyptus spp. e avaliação da diversidade genética por marcadores ISSR. Scientia Forestalis, 47(123), 579-587. http://dx.doi.org/10.18671/scifor.v47n123.19.

Harrington, T. C., Thorpe, D. J., \& Alfenas, A. C. (2011). Genetic variation and variation in aggressiveness to native and exotic hosts among Brazilian populations of Ceratocystis fimbriata. Phytopathology, 101(5), 555-566. PMid:21190423. http://dx.doi.org/10.1094/PHYTO-08-10-0228.

Indústria Brasileira de Árvores - IBÁ. (2018). Relatório IBÁ. 2019. Ano base 2018. Brasília: IBA. Retrieved in 2020, February 5, from http://iba.org/publicações

Keogh, R.M. (2009). The future of teak and the high-grade tropical hardwood sector. FAO Planted Forests and Trees Working Paper Series FP/44. Rome: FAO. Retrieved in 2020, February 5, from http://www.fao.org/forestry/plantedforests/67508@170537/en/.

Kollert, W., \& Cherubini, L. (2012). Teak resources and market assessment 2010. FAO Planted Forests and Trees Working Paper FP/47/E. Rome: FAO. Retrieved in 2020, February 5, from http://www.fao.org/forestry/ plantedforests/67508@170537/en/.

Kollert, W., \& Walotek, P. J. (2015). Global teak trade in the aftermath of Myanmar's log export ban. FAO Planted Forests and Trees Working Paper FP/49/E. Rome: FAO. Retrieved in 2020, February 5, from http://www. fao.org/forestry/plantedforests/67508@170537/en/.

Mafia, R. G., Alfenas, A. C., Ferreira, E. M., \& Binoti, D. H. B. (2011). Método de seleção e identificação de fontes de resistência à murcha do eucalipto causada por Ceratocystis fimbriata. Revista Árvore, 35(4), 817-824. http://dx.doi.org/10.1590/S0100-67622011000500007. 
Mafia, R. G., Ferreira, M. A., Zauza, E. A. V., Silva, J. F., Colodette, J. L., \& Alfenas, A. C. (2013). Impact of Ceratocystis wilt on eucalyptus tree growth and cellulose pulp yield. Forest Pathology, 43, 379-385. http://dx.doi.org/10.1111/efp.12041.

Moller, W. J., \& Devay, J. E. (1968). Carrot as a species selective isolation medium for Ceratocystis fimbriata. Phytopathology, 58(1), 123-124.

Moya, R., Bond, B., Quesada-Pineda, H. (2014). A review of heartwood properties of Tectona grandis trees from fast-growth plantations. Wood Science and Technology, 48(2), 411-433.

Oliveira, L. S. S., Damacena, M. B., Guimarães, L. M. S., Siqueira, D. L., \& Alfenas, A. C. (2016). Ceratocystis fimbriata isolates on Mangifera indica have different levels of aggressiveness. European Journal of Plant Pathology, 145(4), 847-856. http://dx.doi.org/10.1007/s10658-016-0873-2.

Oliveira, R. G. S. (2017). Murcha-de-ceratocytis em eucalipto: método de detecção não destrutivo e precoce da resistência e aspectos morfológicos e anatômicos da infecção (Tese de doutorado). Centro de Ciências Agrárias e Engenharias, Universidade Federal do Espírito Santo, Espirito Santo.

Pandey, D., \& Brown, C. (2000). Teak: a global overview: an overview of global teak resources and issues affecting their future outlook. Unasylva, 201(5), 3-13.

Parke, J. L., Oh, E., Voelker, S., Hansen, E. M., Buckles, G., \& Lachenbruch, B. (2007). Phytophthora ramorum colonizes tanoak xylem and is associated with reduced stem water transport. Phytopathology, 97(12), 1558-1567. PMid:18943716. http://dx.doi.org/10.1094/PHYTO-97-12-1558.

Shaner, G., \& Finney, R. E. (1977). The effect of nitrogen fertilization on the expression of slowmildewing resistance in Knox wheat. Phytopathology, 70, 1051-1056.

Silva, A. C., Betancourth, B. M. L., Ferreira, D. C., Elerati, T. L., Rodrigues, F. A., \& Alfenas, A. C. (2020). Responses of resistant and susceptible hybrid clones of Eucalyptus urophylla $\times$ Eucalyptus grandis to infection by Ceratocystis fimbriata. Annals of Forest Science, 77(45), 1-19. http://dx.doi.org/10.1007/s13595-020-00932-6.

Silva, A. C., de Oliveira Silva, F. M., Milagre, J. C., Omena-Garcia, R. P., Abreu, M. C., Mafia, R. G., NunesNesi, A., \& Alfenas, A. C (2018). Eucalypt plants are physiologically and metabolically affected by infection with Ceratocystis fimbriata. Plant Physiology and Biochemistry, 123, 170-179. PMid:29247937. http://dx.doi.org/10.1016/j.plaphy.2017.12.002.

Silva, G. F., Oliveira, O. M., Mendonça, A. R., \& Fraga Filho, C. V. (2017). Acurácia do método de pressler e fator de forma na estimação do volume de árvores de Tectona grandis L.f. Revista Brasileira de Biometria, 35(2), 213-225.

Valdetaro, D. C. O. F. (2016). Genetic variability of Ceratocystis fimbriata on Tectona grandis and Carapa guianensis in Brazil (Tese de doutorado). Universidade Federal de Viçosa, Viçosa.

Valdetaro, D. C. O. F., Oliveira, L. S. S., Guimaraes, L. M. S., Harrington, T. C., Ferreira, M. A., Freitas, R. G., \& Alfenas, A. C. (2015). Genetic variation, morphology and pathogenicity of Ceratocystis fimbriata in Hevea brasiliensis in Brazil. Tropical Plant Pathology, 40(3), 184-192. http://dx.doi.org/10.1007/s40858-015-0036-6.

Zauza, E. A. V., Alfenas, A. C., Harrington, T. C., Mizubuti, E. S., \& Silvai, J. F. (2004). Resistance of Eucalyptus clones to Ceratocystis fimbriata. Plant Disease, 88(7), 758-760. PMid:30812489. http://dx.doi.org/10.1094/PDIS.2004.88.7.758.

Authors' contributions: CACO: Data curation, Formal Analysis, Investigation, Writing - original draft, Writing review \& editing; GMJM and FASS: Data curation, Investigation, Visualization; IVA, AFA e SCP: Project administration, Software, Supervision; TASG, KLA and LGN: Conceptualization, Funding acquisition, Methodology, Supervision, Writing - original draft, Writing - review \& editing. 